\title{
PROFIL USAHA, PENDAPATAN DAN KONSUMSI RUMAH TANGGA PEMBUDIDAYA IKAN DI DESA CIKIDANG BAYABANG, CIANJUR, JAWA BARAT
}

\author{
Tenny Apriliani, Hakim Miftahul Huda dan Zahri Nasution' \\ ${ }^{1}$ Peneliti pada Balai Besar Riset Sosial Ekonomi Kelautan dan Perikanan \\ JI. KS Tubun Petamburan VI Jakarta 10260. \\ Telp. (021)53650162, Fax. (021)53650159 \\ Diterima 20 Juli 2010 - Disetujui 26 Oktober 2010
}

\begin{abstract}
ABSTRAK
Waduk Cirata di Kabupaten Cianjur merupakan salah satu perairan umum dengan intensitas budidaya ikan yang tinggi di Provinsi Jawa Barat. Kegiatan budidaya di Waduk Cirata menggunakan teknologi budidaya ikan pada karamba jaring apung (KJA) yang saat ini sudah berkembang pesat di beberapa danau dan waduk seperti Saguling dan Jatiluhur. Penelitian ini bertujuan untuk menganalisa kegiatan usaha budidaya ikan dengan teknologi KJA di Desa Cikidang Bayabang dengan mengkaji perkembangan usaha, pendapatan dan konsumsi rumah tangga pembudidaya ikan. Desa Cikidang Bayabang merupakan salah satu desa terpilih mewakili tipologi perikanan budidaya pada KJA dari kegiatan riset PANELKANAS. Penelitian ini menggunakan metode survei dan wawancara untuk pengumpulan data serta metode statistik deskriptif untuk analisis data. Hasil penelitian menunjukkan bahwa dilihat dari usaha, pendapatan dan konsumsinya budidaya ikan di KJA di Desa Cikidang Bayabang masih menjanjikan tetapi masih diperlukan dukungan pemerintah untuk lebih memajukan kegiatan budidaya perikanan.
\end{abstract}

Kata Kunci : usaha, budidaya, karamba jaring apung, Desa Cikidang Bayabang

Abstract : Profile of Business, Income and Consumption of Fish Culture Households lin Cikidang Bayabang Village, Cianjur District, West Java Province By: Tenny A priliani, Hakim Miftahul Huda and Zahri Nasution

Cirata reservoir in Cianjur District is one of open water used for intensive fish culture in West Java province. Fish culture in Cirata reservoir uses a floating net cage (locally known as KJA) technology which now growing expansively in some lakes and reservoirs in West Java such as Saguling and Jatiluhur. This research aims to analyze fish culture activities with cage culture technology in Cikidang Bayabang Village by examining business development, income and consumption of fish farmers. This village is considered a selected site of the PANELKANAS research representing typology of fish cage aquaculture. This research uses a survey method and interviews to collect data in May 2010 and descriptive statistical methods for data analysis. This research confirms that fish culture business, income and consumption in the cage fish farming in Cikidang Bayabang is still promising activities but it need supports from government to improve it.

Keywords : bussiness, aquaculture, floating net system, Cikidang Bayabang Village 


\section{PENDAHULUAN}

Waduk sebagai bagian dari perairan umum mempunyai potensi besar untuk dikembangkan sebagai tempat budidaya ikan. Teknologi budidaya ikan pada keramba jaring apung (KJA) saat ini sudah berkembang pesat di beberapa danau dan waduk seperti Saguling, Cirata dan Jatiluhur. Pada perkembangannya budidaya ikan di KJA memegang peranan penting dalam pembangunan perikanan. Kebutuhan ikan air tawar khususnya ikan konsumsi di Pulau Jawa sebesar $35 \%$ berasal dari perikanan budidaya di KJA (Handayani, 2007).

Hasil sensus yang dilakukan oleh Dinas Perikanan Propinsi Jawa Barat tahun 2002 menunjukkan jumlah keramba jaring apung mencapai 33.000 petak keramba. Tahun 2003 Badan Pengelola Waduk Cirata (BPWC) melakukan sensus dan jumlah keramba meningkat menjadi 39.690 petak keramba dengan jumlah Rumah Tangga Perikanan (pembudidaya) sebanyak 3.899 RTP. Selanjutnya pada tahun 2007 jumlah keramba mencapai 51.418 petak keramba dengan jumlah pembudidaya sebanyak 2.838 RTP yang 22.800 petak dan 1.385 RTP diantaranya berada di Kabupaten Cianjur (Anonimous, 2010).

Data Jawa Barat Dalam Angka tahun 2006 menunjukkan bahwa produksi ikan jaring apung untuk wilayah Kabupaten Cianjur sebanyak 32.158,65 ton dengan nilai 177.484 juta rupiah dan berada pada posisi teratas produksi jaring apung di wilayah Jawa Barat. Selanjutnya Kabupaten Purwakarta sebanyak 18.692 ton dengan nilai 103.161 juta rupiah, dan ketiga adalah Kabupaten Bandung sebanyak $13.126,66$ ton dengan nilai 72.446 juta rupiah (Prihadi, 2005).

Jumlah keramba jaring apung dan produksi perikanan yang besar telah memberikan kontribusi besar dalam kehidupan masyarakat di sekitar Waduk Cirata. Berdasarkan data tersebut maka rperlu dilakukan penelitian ini tentang perkembangan usaha budidaya ikan pada KJA di daerah utama kegiatan budidaya Desa Cikidang Bayabang, Kecamatan Mande, Kabupaten Cianjur Provinsi Jawa Barat. Penelitian ini bertujuan untuk mengetahui keberlanjutan usaha budidaya ikan ditinjau dari aspek ekologi, sosial dan ekonomi pada keramba jaring apung yang ada di Desa Cikidang Bayabang. Penelitian ini dilaksanakan di lokasi riset Panel Perikanan dan Kelautan Nasional bidang budidaya.

\section{METODOLOGI}

\section{Lokasi dan Waktu Penelitian}

Penelitian dilaksanakan di Desa Cikidang Bayangbang yang merupakan salah satu lokasi riset Panel Perikanan dan Kelautan Nasional bidang budidaya. Lokasi tersebut memiliki dinamika sosial ekonomi rumah tangga pembudidaya ikan di KJA. Penelitian di dilaksanakan pada Bulan Mei Tahun 2010 di Desa Cikidang Bayabang, Kecamatan Mande, Kabupaten Cianjur, Provinsi Jawa Barat.

\section{Jenis dan Sumber Data}

Data yang dikumpulkan meliputi data primer dan data sekunder. Data primer dikumpulkan untuk mengetahui kondisi aktual usaha perikanan budidaya pada tingkat pembudidaya. Data primer yang dikumpulkan mencakup kuantitas dan kualitas input output serta kelembagaan dalam usaha budidaya ikan pada KJA. Sumber data primer adalah responden pembudidaya ikan pada KJA. Data sekunder dikumpulkan untuk mengetahui kondisi umum usaha perikanan budidaya di Desa Cikidangbayabang dan Waduk Cirata. Sumber data sekunder diantaranya adalah laporan statistik perikanan Kabupaten Cianjur dan data profil Desa Cikidang Bayabang serta hasil penelitian atau makalah terkait kegiatan perikanan di Waduk Cirata.

\section{Metode Pengumpulan Data}

Pengumpulan data primer dilakukan melalui wawancara terhadap pembudidaya ikan yang terpilih sebagai responden. Jumlah 
responden sebanyak 32 orang. Penentuan responden dilakukan melalui stratified random sampling berdasarkan skala usaha dan pola usaha yang dilaksanakan. Kelompok usaha dikelompokkan menjadi dua. Pertama, skala mikro (pembudidaya yang memiliki KJA kurang dari dua (2) unit) dan skala kecil (kepemilikan 2-10 unit KJA). Data sekunder dikumpulkan dengan melakukan studi literatur, dan wawancara dengan informan kunci dari pihak Dinas Perikanan Cianjur dan perangkat Desa Cikidang Bayabang.

\section{Metoda Analisis Data}

Data yang telah ditabulasi kemudian dianalisis secara deskriptif dengan maksud untuk memberikan gambaran permasalahan secara komprehensif. Statistik deskriptif digunakan untuk mencari jumlah sampel, nilai maksimum dan minimum, rata-rata dan standar deviasinya. Hasil dari analisis kemudian diinterpretasikan untuk menjawab tujuan penelitian. Analisis dilakukan pada modul usaha, pendapatan, konsumsi dan kelembagaan. Untuk modul usaha dilakukan analisa usaha dilakukan dengan menghitung besar biaya tetap, variabel, dan total penerimaan selama satu tahun sehingga diketahui struktur biaya, penerimaan, dan besarnya keuntungan. Penghitungan keuntungan usaha menggunakan rumus :

$$
ת=\mathrm{TR}-\mathrm{TC}
$$

Total Cost (TC) dihitung melalui rumus :

$\mathrm{TC}=\mathrm{FC}+\mathrm{VC}$

Dimana $л=$ Keuntungan Usaha

$\mathrm{TR}=$ Total Penerimaan/Total Revenue

TC $=$ Total Biaya/Total Cost

$\mathrm{FC}=$ Biaya Tetap/Fixed Costs

VC = Biaya Variabel/Variable Costs

RC Ratio diperoleh melalui rumus :

RC Ratio $=\frac{T R}{T C}$
Analisis pendapatan rumah tangga perikanan bertujuan untuk mengetahui besarnya pendapatan yang berasal dari pendapatan utama dan sampingan baik itu yang berasal dari kepala keluarga maupun anggota rumah tangganya. Analisis konsumsi digunakan untuk mengetahui besarnya konsumsi rumah tangga perikanan yang berasal dari konsumsi pangan dan non pangan.

\section{HASIL DAN PEMBAHASAN}

\section{Deskripsi Lokasi Penelitian}

Desa Cikidang Bayabang berjarak tempuh sekitar setengah jam dari kota Cianjur. Banyak pilihan akses ke desa tersebut dengan menggunakan sepeda motor atau mobil dengan kondisi jalan aspal dan baik. Desa Cikidang Bayabang merupakan desa yang dinilai dapat mewakili desa perikanan budidaya untuk budidaya pembesaran ikan di Keramba Jaring Apung (KJA). Secara administratif luas wilayah Desa Cikidang Bayabang adalah $700 \mathrm{Ha}$. Iklim di desa ini termasuk iklim basah dengan rata-rata curah hujan $226 \mathrm{~mm} /$ tahun. Letak geografis desa tersebut berada pada ketinggian dari permukaan laut 500 meter.

Penduduk Desa Cikidang Bayabang, berjumlah 5.912 orang dengan komposisi pria dan wanita sebesar $51,96 \%$ dan $48,04 \%$. Jumlah Kepala Keluarga (KK) mencapai 1564 KK. Dengan demikian rata-rata satu keluarga didiami oleh 3 sampai dengan 4 orang. Jumlah keluarga yang termasuk keluarga pra sejahtera berjumlah $0,6 \%$. Tingkat pendidikan masyarakat didominasi oleh Iulusan Sekolah Dasar (SD) yang mencapai 62,56 \%, mencapai pendidikan Sekolah Lanjutan Tingkat Pertama (SLTP) 8,72\%, dan tamat Sekolah Lanjutan Tingkat Atas (SLTA) sebanyak $1,69 \%$. Hanya sekitar 5 orang atau kurang dari 0,1\% masyarakat yang berhasil melanjutkan pendidikan ke jenjang perguruan tinggi. 
Sumber mata pencaharian utama penduduk sebenarnya adalah pertanian, namun demikian setelah dibangunnya waduk Cirata dan berkembangnya usaha perikanan, maka pekerjaan di sektor perikanan menjadi mata pencaharian lain dari penduduknya walaupun hanya sebagai buruh tunggu. Hal ini disebabkan budidaya ikan di KJA membutuhkan modal yang cukup banyak. Sarana prasarana perikanan yang banyak tersedia yaitu toko alat perikanan sebanyak tujuh (7) buah, serta agen penjualan pakan. Selain itu lembaga pemasaran ikan yang sudah ada yaitu pedagang ikan grosir sebanyak 20 orang, pedagang eceran sebanyak tujuh (7) orang serta pengolah sebanyak 10 orang.

Budidaya ikan di Waduk Cirata merupakan matapencaharian utama lainnya setelah pertanian. Pengalaman berusaha sebagai pembudidaya ikan telah digeluti cukup lama. KJA di Cirata pada umumnya berukuran $14 \mathrm{~m} \times 14 \mathrm{~m}$ per unitnya. Dalam satu unit KJA biasanya terdiri dari empat petak dan tiap petak mempunyai satu jaring utama. Konstruksi utama KJA terdiri dari kerangka keramba yang biasa terbuat dari besi atau bambu. Kemudian jaring utama atau jaring atas, biasanya berukuran $7 \mathrm{~m} \times 7 \mathrm{~m} \times 4 \mathrm{~m}$ dengan diameter jaring 0,75 " dan 3 jaring ukuran sama dengan diameter mata jaring 1".

Lapis terluar adalah jaring "kolor "yang biasanya melingkupi satu unit keramba atau mempunyai ukuran $14 \mathrm{~m} \times 14 \mathrm{~m} \times 6 \mathrm{~m}$. Selain itu juga terdapat jaring "dolos" yang mirip dengan jaring utama tetapi melingkupi dua petak atau mempunyai ukuran $7 \mathrm{~m} \times 14 \mathrm{~m} \times 4 \mathrm{~m}$. Tiap satu unit kerangka keramba biasanya terdiri dari pelampung sejumlah 36 buah terbuat dari sterofoam atau drum.

Untuk menjaga ikan dalam KJA terdapat rumah jaga yang digunakan sebagai tempat menyimpan pakan, perlengkapan dan tidak jarang sekaligus sebagai tempat tinggal pemilik atau penjaga KJA. Keramba diikat dengan tali dan diberi pemberat atau jangkar yang terbuat dari batu atau besi agar tidak berpindah. Berdasarkan data tahun 2009, jumlah KJA di Desa Cikidang Bayabang telah mencapai 580 unit.

Pemeliharaan ikan di KJA Waduk Cirata dilakukan untuk tujuan komersial, sehingga pemeliharaan ikan dilakukan secara intensif baik dilihat dari padat penebaran dan pakan yang digunakan. Selain itu ruang jaring pun dimanfaatkan secara optimal dengan cara memasang jaring sebanyak tiga lapisan. Lapisan pertama (jaring utama) dipelihara ikan mas, lapisan kedua (jaring dolos) dipelihara ikan nila dan pada lapisan ketiga (jaring kolor) dipelihara ikan catfish.

Jenis ikan yang dibudidaya tergantung pada permintaan pasar atau komoditas yang ramai dibeli. Namun demikian komoditas utamanya dan selalu dibudidayakan dari dulu sampai sekarang adalah ikan mas dan jenis ikan lainnya meliputi Ikan Patin (Pangasius $S p)$, nila (Oreochromis niloticus), bawal (Colosoma macropomum). Pakan yang digunakan adalah pakan komersial dengan pemberian pakan yang cukup.

Jenis pakan yang digunakan adalah pelet. Setelah dipelihara selama 120 hari, ikan mas tumbuh mencapai ukuran konsumsi 250 s/d 300 gram per ekor. Sedangkan nila dapat dipanen setelah berumur 6-8 bulan. Produktivitas rata-rata untuk ikan mas yaitu 1200 kg/unit dan ikan nila 800 kg/unit. Pemeliharaan ikan nila pada jaring lapis kedua (jaring dolos). dimaksudkan untuk memanfaatkan sisa pakan yang tidak dimakan oleh ikan ma atau patin yang dipelihara di jaring lapis pertama. Pemeliharaan ikan nila tersebut menambah penghasilan karena pembudidaya menganggapnya adalah sebagai tabungan. Lama pemeliharaan ikan dalam jaring dolos berkisar 6 bulan atau dalam satu tahun dapat melakukan panen sebanyak dua kali. Selain usaha pembesaran untuk konsumsi, beberapa pembudidaya ikan juga melakukan usaha penggelondongan ikan, yaitu memelihara benih selama 10 hari sampai 1 bulan untuk dijual kembali sebagai benih untuk dibesarkan. 


\section{Karakteristik Sampel Responden}

Karakteristik pembudidaya ikan di lokasi penelitian dilihat dari beberapa aspek yakni umur, pendidikan dan jumlah tanggungan keluarga, (Gambar 1).

Tinggi rendahnya umur seseorang dapat mempengaruhi suatu keberhasilan usaha dan mempunyai peranan penting dalam karakteristik individu, di samping itu umur sangat berpengaruh terhadap kemampuan seseorang dalam mempelajari, memahami, menerima dan mengadopsi inovasi baru, biasanya usia yang relatif muda akan lebih cepat dalam mengambilan keputusan teknologi yang akan diadopsi. Menurut Kamaludin (1994) bahwa umur digolongkan dalam 3 kategori golongan 1, usia tidak produktif ( $<25$ dan $>65$ tahun), 2. usia produktif ( $>45$ sampai 65 tahun) dan
3 usia sangat produktif (25 sampai 45 tahun). Dilihat dari persentase sebaran umur responden, pada umumnya responden berusia antara 25 - 45 tahun yaitu sebesar $53 \%$ dan kisaran usia $>45-65$ tahun sebesar $41 \%$. Kisaran usia ini menunjukkan bahwa umur responden termasuk dalam kategori yang sangat produktif dan produktif untuk melakukan kegiatan usaha.

Tingkat pendidikan sebagian besar pembudidaya ikan pada KJA di Desa Cikidang Bayabang adalah tamatan Sekolah Dasar. Latar belakang pendidikan yang rendah sedikit banyak mempengaruhi pola pikir pembudidaya dalam manajemen usaha budidaya ikan. Manajemen usaha sebagian besar pembudidaya cenderung tradisional dan hanya mengandalkan pengalaman usaha. Pengetahuan pembudidaya terhadap teknis

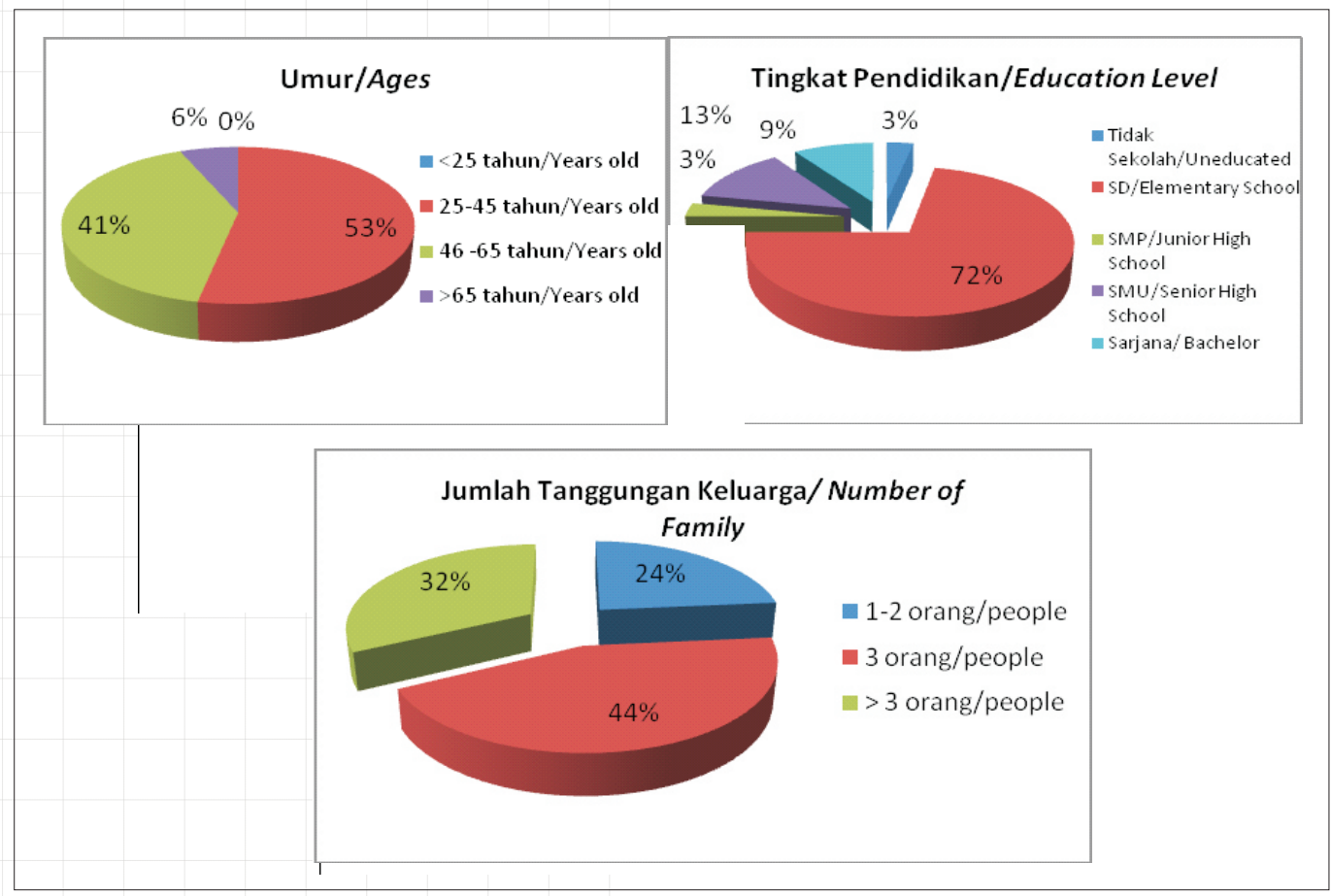

Gambar 1. Karakteristik Responden Pembudidaya Ikan di KJA di Desa Cikidang Bayabang, Cianjur, Jawa Barat, Tahun 2010

Figure 1. Characteristic of Fish Farmer in Floating Cage Respondent at the Cikidang Bayabang Village, Cianjur, West Java, Year 2010 
budidaya masih minim sehingga antisipasi dan respon terhadap serangan penyakit pada ikan kurang mencukupi. Serangan penyakit yang mengakibatkan kematian ikan sering terjadi dan dibiarkan begitu saja tanpa melakukan upaya penanggulangan. Beberapa hal yang mengakibatkan rendahnya tingkat pendidikan di Desa Cikidang Bayabang adalah umumnya rumah tangga tinggal di kolam sehingga biaya transportasi yang dikeluarkan untuk ke sekolah cukup tinggi.

Dari sisi jumlah tanggungan keluarga, rumah tangga responden didominasi oleh jumlah tanggungan sebanyak tiga (3) orang yaitu istri dan dua (2) orang anak sebesar $44 \%$. Hal ini menunjukkan bahwa sebagian besar rumah tangga sudah semakin sadar akan pentingnya untuk mempertimbangkan jumlah anggota keluarga karena akan terkait dengan pengeluaran untuk memenuhi kebutuhan hidup sehari-harinya.

\section{Keragaan Teknis Budidaya Ikan di Keramba Jaring Apung (KJA) dan Musim Tanam di Lokasi Penelitian}

KJA di Desa Cikidang Bayabang umumna mempunya ukuran $14 \mathrm{~m} \times 14 \mathrm{~m} \times 6 \mathrm{~m}$ per unitnya. Dalam satu unit KJA biasanya terdiri dari empat petak dan tiap petak mempunyai satu jaring utama. Konstruksi utama KJA terdiri dari kerangka yang biasa terbuat dari besi atau bambu. Kemudian jaring utama atau jaring atas, biasanya berukuran $6 \mathrm{~m} \times 6 \mathrm{~m} \times 4 \mathrm{~m}$ dengan diameter jaring 0,75 " dan 3 jaring ukuran sama dengan diameter mata jaring 1". Lapis terluar adalah jaring kolor yang biasanya melingkupi satu unit keramba atau mempunyai ukuran 14 $\mathrm{m} \times 14 \mathrm{~m} \times 6 \mathrm{~m}$. Selain itu juga terdapat jaring dolos yang mirip dengan jaring utama tetapi melingkupi dua petak atau mempunyai ukuran $6 \mathrm{~m} \times 12 \mathrm{~m} \times 3 \mathrm{~m}$. Tiap satu unit kerangka keramba biasanya terdiri dari pelampung sejumlah 36 buah terbuat dari sterofoam atau drum.

Jenis ikan utama yang dipelihara adalah ikan mas dan nila. Pada beberapa pembudidaya juga memelihara jenis ikan bawal, gurame atau patin tetapi tidak dalam jumlah banyak. Pola budidaya yang dilakukan pembudidaya umumnya adalah polikultur. Dimana pada jaring utama dipelihara ikan mas atau bawal kemudian ikan nila berada di jaring kolor atau di bawah jaring utama. Ukuran benih untuk pembesaran ikan Mas adalah 10-15 gram sedangkan untuk pembesaran nila adalah 8-10 gram. Benih ikan biasanya dipasok dari Bandung, Cianjur, Sukabumi dan Subang. Pemberian pakan biasanya tiga kali sehari, tetapi pembudidaya ada yang memberi pakan sampai lima kali dalam sehari. Jenis pakan yang digunakan adalah pelet. Benih ikan mas ukuran 15 gram dapat tumbuh mencapai ukuran konsumsi 250 s/d 300 gram dalam waktu 120 hari. Sedangkan nila dapat dipanen setelah berumur $6-8$ bulan.

\section{Struktur Penerimaan dan Pembiayaan Usaha Budidayalkan di KJA}

Pembudidaya ikan pada keramba jaring apung (KJA) di Desa Cikidang Bayabang yang menjadi responden sebagian besar mengusahakan ikan mas dan nila sebagai komoditas utama usahanya. Usaha budidaya ikan pada KJA di Desa Cikidang Bayabang didominasi oleh skala usaha mikro dan kecil dengan komoditas usaha yang relatif homogen. Konstruksi KJA umumnya adalah jaring ganda yang terdiri dari jaring atas dan bawah. Komoditas yang dipelihara adalah ikan mas untuk jaring atas dan ikan nila pada jaring bawah. Walaupun demikian ada juga pembudidaya yang memelihara ikan bawal sebagai komoditas utama.

Keragaan usaha dalam RTP budidaya pada KJA di Cikidang Bayabang yang biasanya berpengaruh terhadap pendapatan usaha adalah jumlah unit KJA, pola budidaya dan jenis komoditas ikan dan status kepemilikan aset (sebagai pemilik atau pandega/penjaga). Investasi usaha budidaya ikan dengan sistem KJA untuk skala mikro dengan jumlah KJA kurang dari 2 unit rata-rata berjumlah Rp. 33.975.167,- dimana persentase yang paling besar digunakan untuk 
pembelian KJA dan pembangunan rumah jaga dimana masing-masing sekitar $41,21 \%$ dan $32,38 \%$. Sedangkan usaha budidaya ikan dengan skala kecil yaitu dengan jumlah KJA antara 2-10 unit biaya investasi rata-rata yang dikeluarkan adalah sebesar Rp. 57.022.060,--. Persentase terbesar yang digunakan seperti halnya pada skala mikro yaitu untuk pembelian KJA yaitu sebesar $51,73 \%$. Secara lengkap struktur aset dan investasi dapat dilihat pada Tabel 1.

Komponen biaya tetap meliputi penyusutan sarana produksi, biaya listrik, retribusi, pemeliharaan sarana produksi, dan upah karyawan. Biaya variabel meliputi biaya benih ikan dan biaya pakan. Rincian lengkap perhitungan biaya, penerimaan dan keuntungan usaha pembudidaya ikan pada

Tabel 1. Struktur Aset dan Investasi Usaha Budidaya Ikan pada KJA per tahun di Desa Cikidang Bayabang, Mande, Cianjur, Jawa Barat, 2010

Table 1. Asset and Business Investment Structure of Fish Culture in Floating Cage per Year in the Cikidang Bayabang, Mande, Cianjur, West Java, 2010

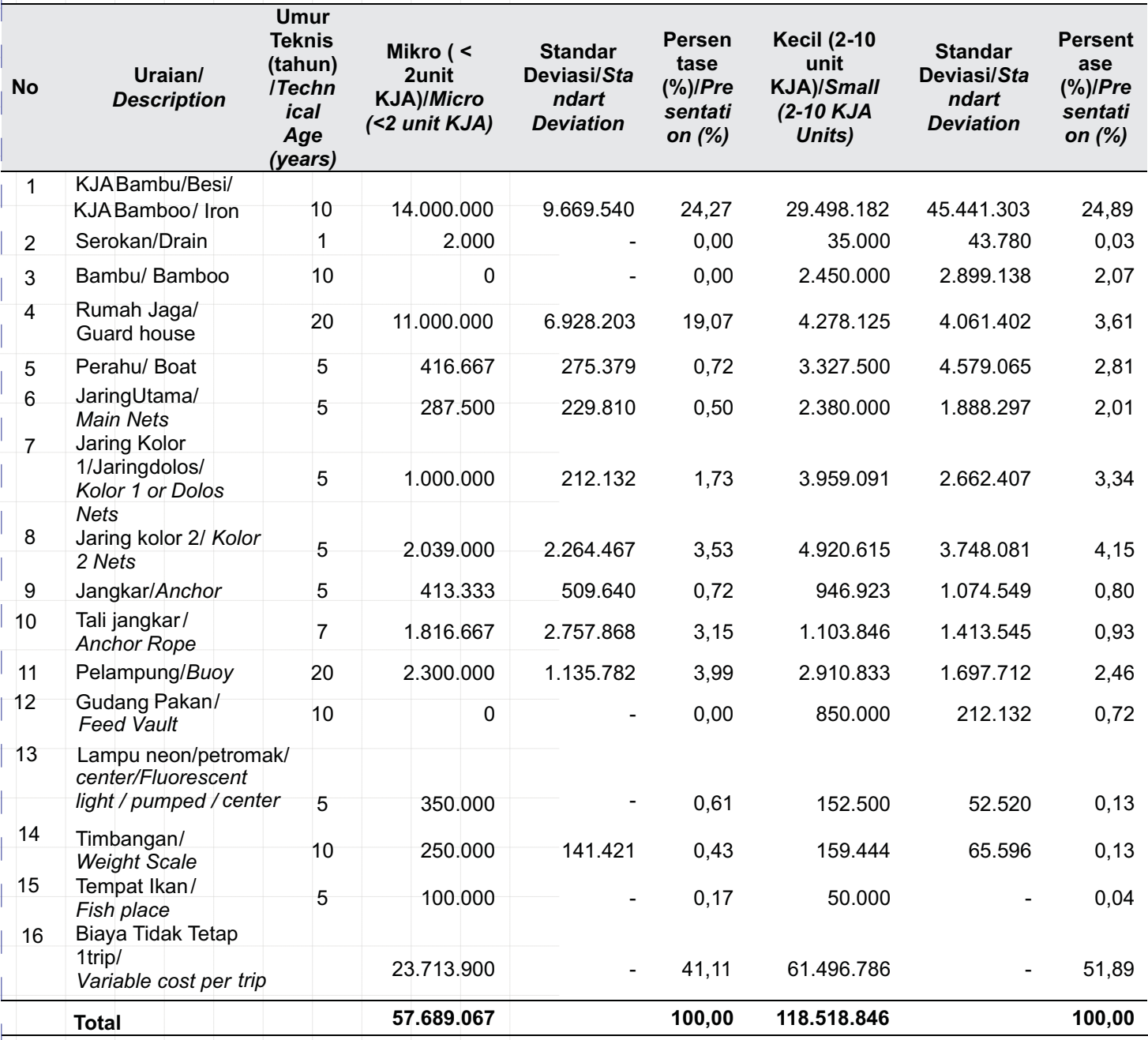

Sumber: Data Primer (diolah), 2010/ Source: Primary Data (Processed), 2010 
Tabel 2. Struktur Biaya Tetap Usaha Budidaya Ikan pada KJA per Tahun di Desa Cikidang Bayabang, Mande, Cianjur, Jawa Barat, 2010

Table 2. Fixed Cost Structure of Fish Culture in Floating Cage per Year in Cikidang Bayabang, Mande, Cianjur, West Java, 2010

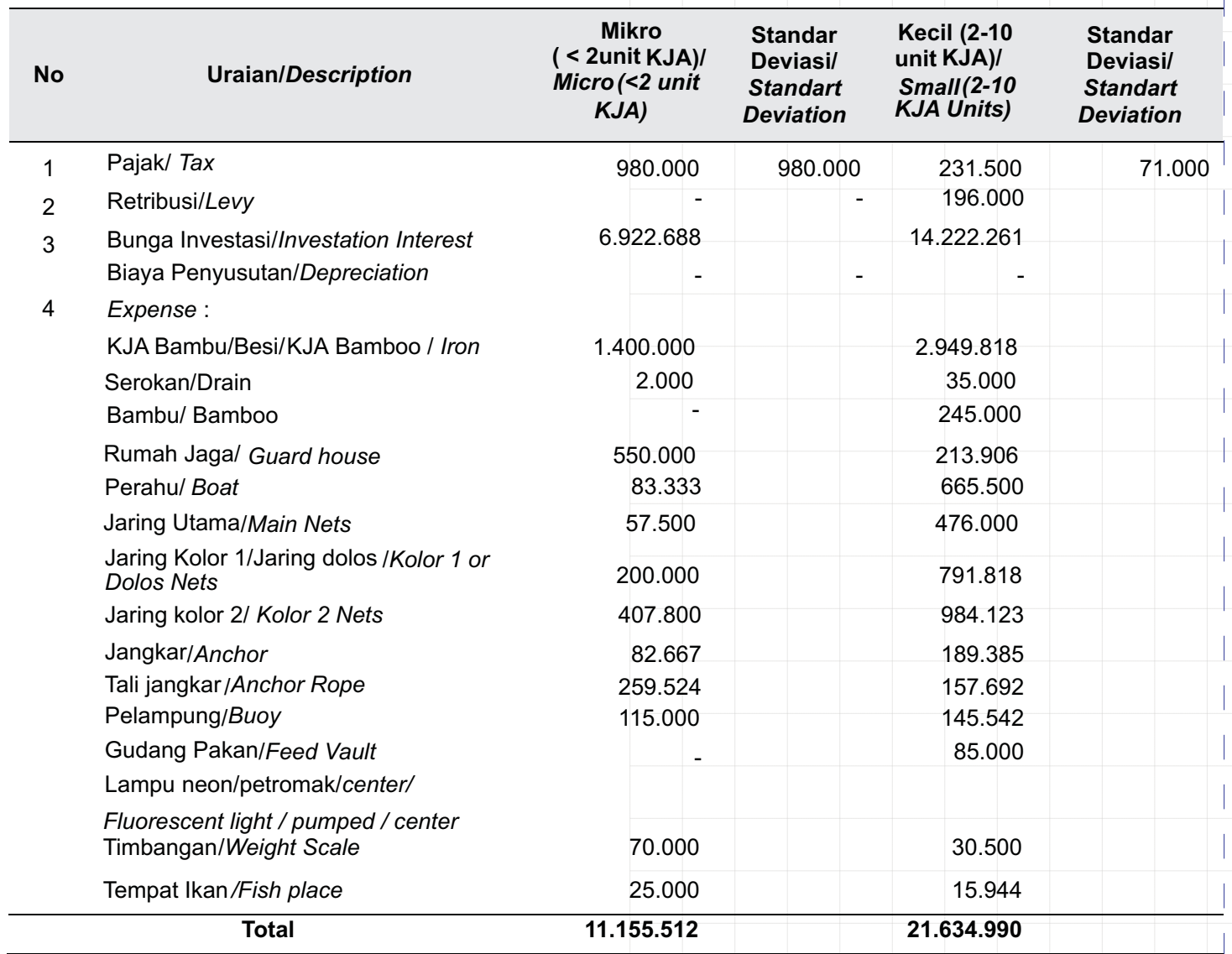

Sumber:Data Primer (diolah), 2010/Source: Primary Data (Processed), 2010

KJA di Desa Cikidang Bayabang dapat dilihat pada Tabel 2.

Struktur biaya operasional usaha budidaya pada KJA masih didominasi oleh kebutuhan pakan pelet, dan benih. Input usaha yang paling berpengaruh dalam usaha budidaya ikan pada KJA adalah pakan. Jumlah pakan yang diberikan selama masa pemeliharaan ikan mempengaruhi jumlah ikan yang berhasil dipanen. Semakin besar jumlah pakan yang diberikan maka semakin besar pula berat ikan yang bisa dipanen. Intensitas usaha budidaya pada sebagian besar responden mengalami penurunan yang disebabkan oleh keterbatasan modal yang dimiliki. Harga pakan yang tinggi dan rendahnya produktivitas menjadi alasan beberapa pembudidaya untuk mengurangi intensitas usahanya. Kolam KJA tidak diisi optimal atau banyak petak KJA yang dibiarkan kosong, begitu juga dengan pemberian pakan yang hanya sedikit. Harga komoditas ikan mas pada akhir bulan April 2010 berkisar antara Rp10.500 - Rp11.000 merupakan harga terendah yang pernah dirasakan pembudidaya ikan. Struktur biaya biaya tetap dapat dilihat pada Tabel 3 


\section{Tabel 3. Struktur Biaya Tidak Tetap Usaha Budidaya Ikan pada KJA per Tahun di Desa} Cikidang Bayabang, Mande, Cianjur, Jawa Barat, 2010

Table 3. Variabel Cost of Fish Culture in Floating Cage per Year at Cikidang Bayabang, Mande, Cianjur, West Java, 2010

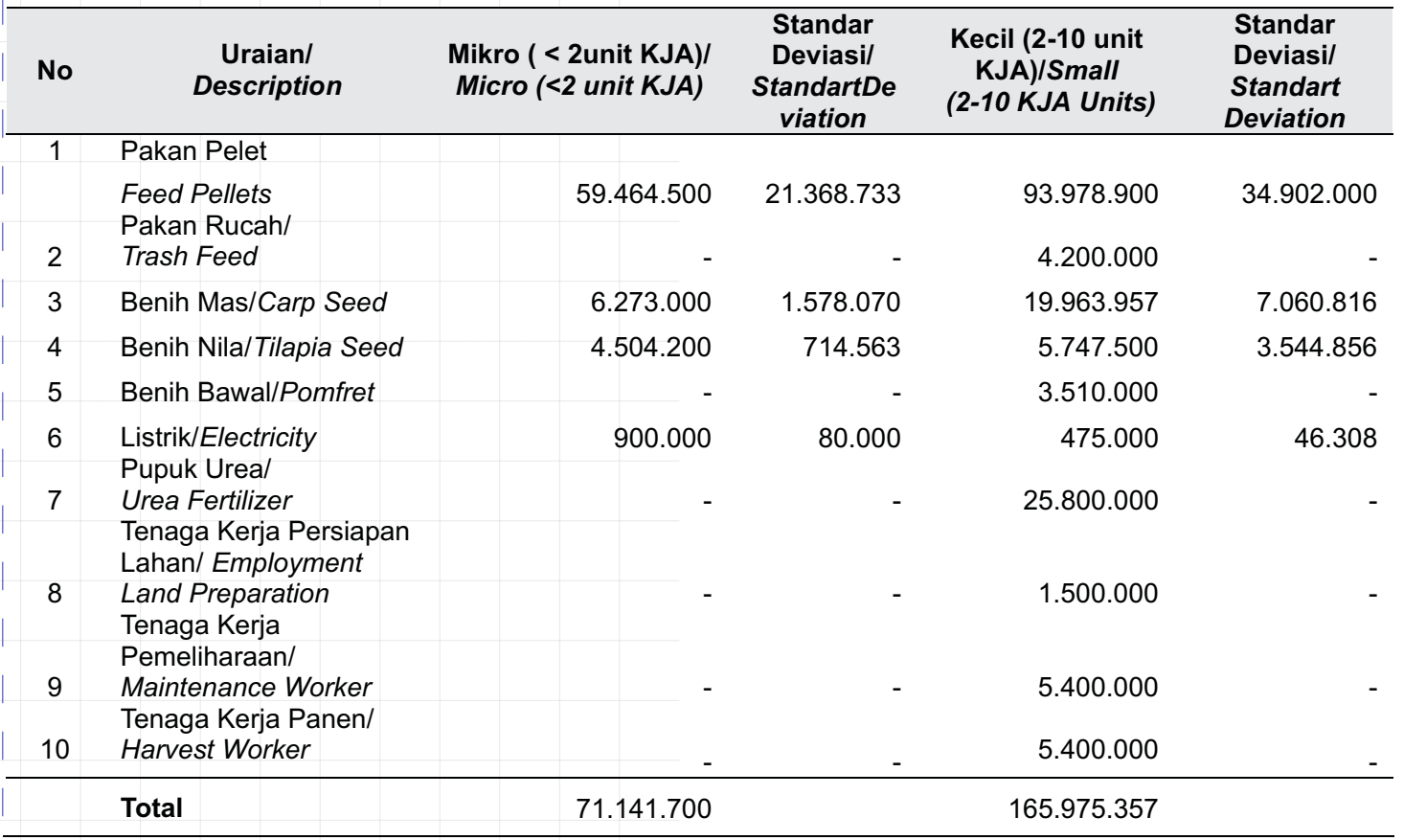

Sumber: Data Primer (diolah), 2010/Source: Primary Data (Processed), 2010

Jenis ikan yang dibudidayakan adalah ikan mas dan ikan nila baik dengan teknik jaring ganda maupun jaring tunggal namun dari 30 responden terdapat satu orang responden yang melakukan budidaya ikan bawal. Rata-rata penerimaan per tahun untuk skala mikro adalah sekitar Rp. 87.292.400,sedangkan untuk pembudidaya skala kecil sekitar Rp. 244.953.407,--(lihat Tabel 4).

Berdasarkan Tabel 5 dapat diketahui bahwa keuntungan usaha budidaya ikan pada KJA dalam satu tahun antara skala mikro dan kecil relatif cukup signifikan yaitu sekitar Rp. 4.995.188 untuk skala mikro dan Rp. 57.343.060 untuk skala kecil. Kondisi ini dapat terjadi karena adanya usaha dari pembudidaya ikan skala kecil untuk menurunkan intensitas produksinya dengan cara membiarkan beberapa KJA dalam keadaan kosong atau mengurangi jumlah pakan yang diberikan. Nilai R/C rasio pada skala usaha mikro dan kecil yang berkisar antara 1,06 dan 1,31 menunjukkan usaha tersebut hanya memberikan keuntungan yang rendah.

Hambatan yang berpengaruh terhadap usaha budidaya ikan pada KJA adalah semakin meningkatnya harga input produksi, khususnya harga pakan ikan. Kenaikan harga pakan ikan sebesar Rp.100-Rp.500 per kilogram sangat mempengaruhi keuntungan usaha pembudidaya ikan.

Harga pakan ikan berkisar antara Rp. 4.950- Rp. 5.500 per kilogram. Bahkan, kenaikan harga pakan ikan diperparah dengan tidak stabilnya harga ikan yang dihasilkan. Fluktuasi harga ikan mas pada tahun 2009 berkisar antara Rp.11.000-Rp.16.000 
Tabel 4. Struktur Penerimaan Usaha Budidaya Ikan pada KJA per Tahun di Desa Cikidang Bayabang, Mande, Cianjur, Jawa Barat, 2010

Table 4. Revenue Structure of Fish Culture in Floating Cage per Year at Cikidang Bayabang, Mande, Cianjur, West Java, 2010

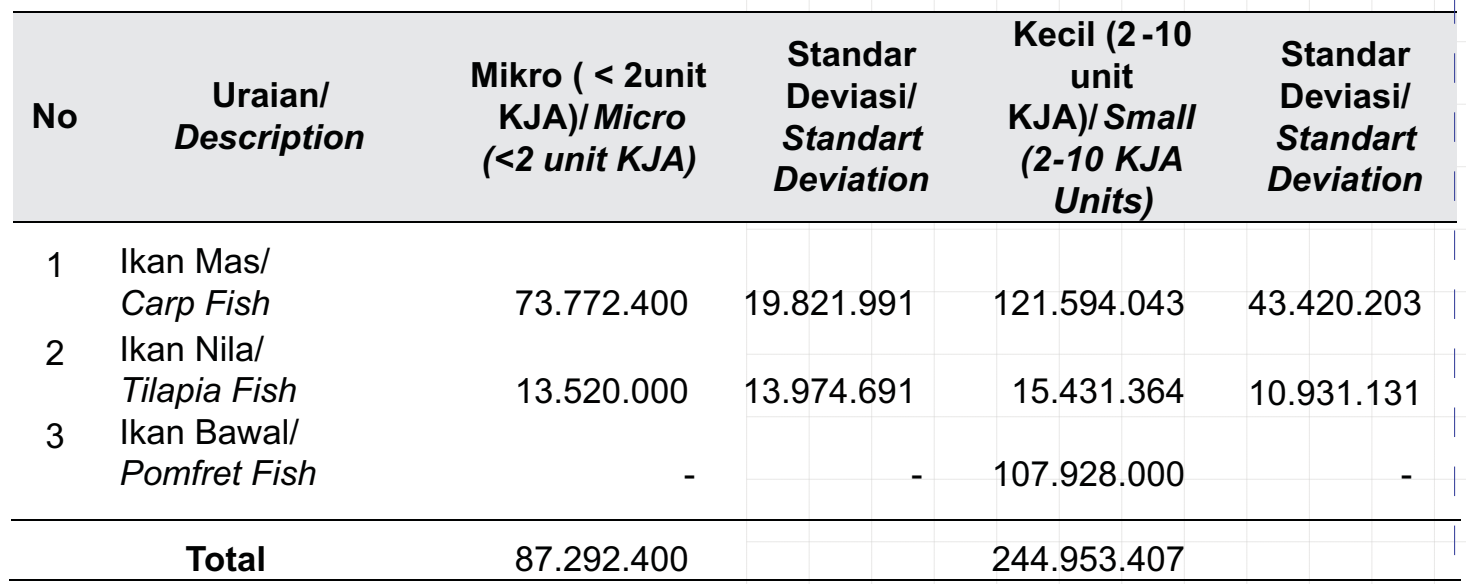

Sumber: Data Primer (diolah), 2010/Source: Primary Data (Processed), 2010

Tabel5. Analisis Usaha Budidaya Ikan pada KJA di Desa Cikidang Bayabang, Mande, Cianjur, Jawa Barat, 2010

Table 5. Rentability of Fish Culture in The Floating Cage in Cikidang Bayabang, Mande, Cianjur, West Java, 2010

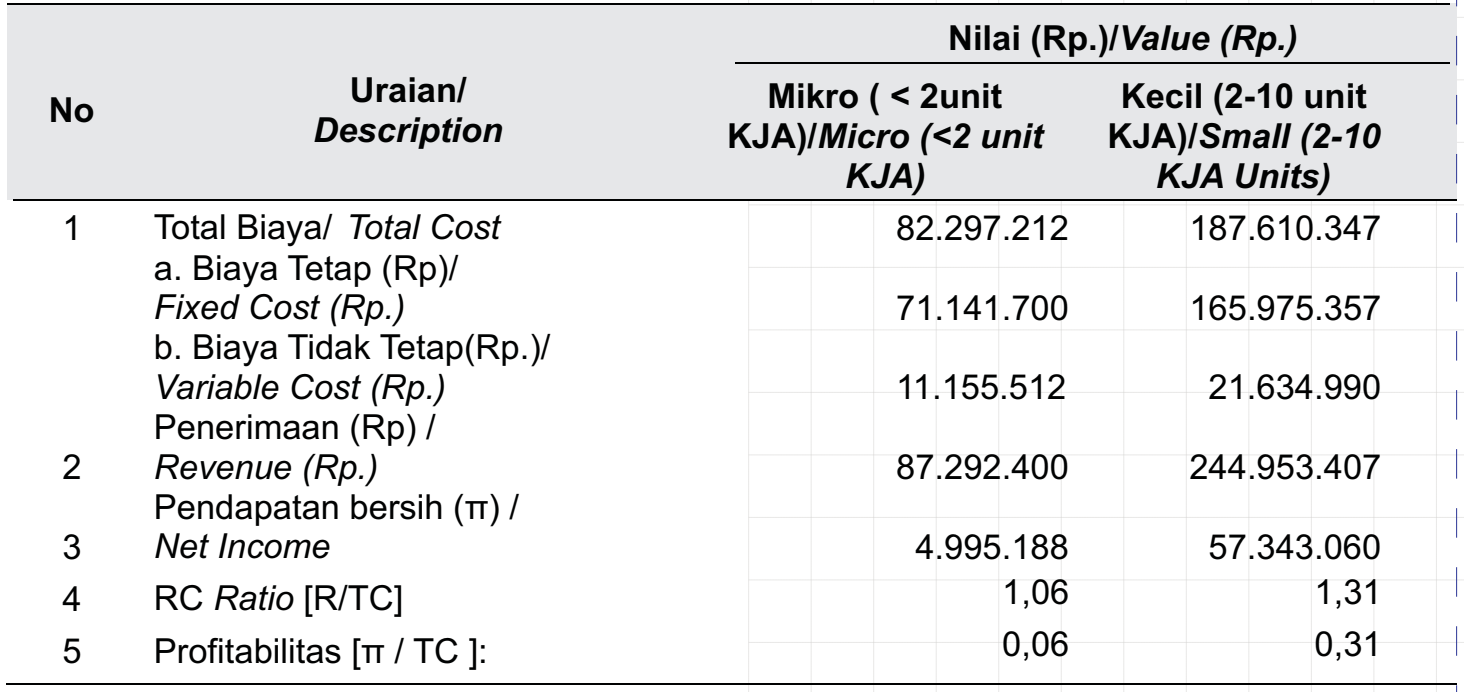

Sumber: Data Primer (diolah), 2010/Source: Primary Data (Processed), 2010 
sedangkan ikan Nila (Oreochromis niloticus) berada pada kisaran Rp. 7.500 - Rp. 10.500. Pada saat dilakukan wawancara, harga ikan Mas (Cyprinus carpio) bahkan mencapai harga terendah selama beberapa tahun terakhir yaitu Rp. 10.500. Sementara itu, harga ikan Bawal (Colosoma macropomum) berkisar pada harga Rp. 6.400 - Rp. 8.000 .

Fluktuasi keuntungan usaha yang diperoleh pembudidaya ikan di Desa Cikidang Bayabang mengakibatkan penjual pakan yang biasa memberikan pinjaman modal berupa pakan mulai mengurangi jumlah pinjaman pakannya. Bahkan, pinjaman pakan yang memegang peranan penting dalam usaha budidaya ikan semakin sulit diperoleh sedangkan pembudidaya ikan mempunyai kemampuan terbatas untuk membeli pakan secara tunai. Kondisi tersebut memaksa sebagian besar pembudidaya ikan untuk mengurangi intensitas usahanya. Keramba jaring apung pembudidaya ikan banyak dikosongkan atau hanya ditebar ikan dalam jumlah sedikit dengan pemberian pakan yang sedikit pula.

Produksi ikan mas yang diperoleh pembudidaya skala mikro dan kecil dalam satu tahun berurutan adalah 9.645 dan 15.536 kilogram. Produksi ikan nila dalam satu tahun untuk skala mikro dan kecil berurutan adalah 2.438 dan 3.293 kilogram. Adapun pakan yang harus dikeluarkan dalam waktu satu tahun pada skala mikro dan kecil berurutan adalah 22.351 dan 30.741 kilogram. Nilai ratarata konversi pakan dengan jumlah produksi ikan Mas yang dihasilkan adalah 43\% pada skala mikro dan $51 \%$ pada skala kecil dengan artian produksi ikan mas yang dihasilkan adalah $43 \%$ dan $53 \%$ atas pakan yang diberikan. Usaha budidaya ikan skala kecil yang memelihara ikan bawal dalam satu tahun menghasilkan produksi sebanyak 13.491 kilogram dengan jumlah pakan yang diberikan sebanyak 20.045 kilogram sehingga konversi pakan terhadap ikan adalah $67 \%$.

\section{Struktur Pendapatan dan Konsumsi Rumah Tangga}

\section{a. Pendapatan Rumah Tangga}

Sumber pendapatan responden berasal dari pekerjaan utama sebagai pembudidaya dan pekerjaan sampingan sebagai petani atau nelayan. Beberapa anggota rumah tangga responden ada yang bekerja, diantaranya dengan membuka warung sedangkan sebagian besar yang lainnya hanya sebagai ibu rumah tangga atau masih sekolah. Kontribusi tambahan juga tidak didapatkan dari hasil penyewaan aset produktif perikanan dan non perikanan. Sementara rata-rata aset barang yang dimiliki berupa rumah, motor, TV, VCD dan meubelair. Struktur pendapatan responden secara lengkap terdapat pada Tabel 6.

Perbedaan rata-rata pendapatan utama rumah tangga responden antara skala mikro dan kecil cukup signifikan yaitu sekitar Rp. 6.000.000,-. Pendapatan kepala keluarga yang berasal dari sampingan sekitar $50 \%$ dari pendapatan dari usaha utamanya. Pendapatan sampingan kepala keluarga antara skala mikro dan skala kecil ternyata lebih besar pada skala mikro, hal ini dikarenakan pembudidaya dengan skala kecil umumnya lebih fokus melakukan usaha KJA nya dibandingkan melakukan usaha sampingan lainnya. Pendapatan dari anggota rumah tangga berasal dari non perikanan sebagai pendapatan utamanya sedang ratarata sebesar Rp. 10.057.000,-. Berdasarkan Tabel 6 dapat dilihat bahwa pendapatan rumah tangga skala mikro didominasi oleh kepala keluarga sedangkan untuk rumah tangga skala kecil pendapatan dari anggota rumah tangga cukup signifikan yaitu sebesar $25 \%$ dari total pendapatan rumah tangga.

\section{b. Konsumsi Rumah Tangga}

Konsumsi rumah tangga, bahan pokok yang dikonsumsi adalah nasi dan bahan lauk protein yang sering dikonsumsi adalah ikan 
Tabel 6. Pendapatan Rumah Tangga Pembudidaya per Tahun Berdasarkan Sumber Pendapatannya di Desa Cikidang Bayabang, Cianjur, 2010

Table 6. Fish Culture Household Income per Year Based on Main Income Sources in Cikidang Bayabang , Cianjur, 2010

\begin{tabular}{|c|c|c|c|c|c|c|}
\hline Kategori/Categorize & $\begin{array}{l}\text { Skala Mikro } \\
\text { (Rp./Thn)/ } \\
\text { MicroScale } \\
\text { (Rp./Year) }\end{array}$ & $\begin{array}{l}\text { Standar } \\
\text { Deviasi/ } \\
\text { Standart } \\
\text { Deviation }\end{array}$ & $\begin{array}{c}\text { Frekuensi } \\
(\%) l \\
\text { Frequency } \\
(\%)\end{array}$ & $\begin{array}{c}\text { Skala } \\
\text { Kecil } \\
\text { (Rp./Thn)/ } \\
\text { Small } \\
\text { Scale } \\
\text { (Rp./Year) }\end{array}$ & $\begin{array}{l}\text { Standar } \\
\text { Deviasi/ } \\
\text { Standart } \\
\text { Deviation }\end{array}$ & $\begin{array}{l}\text { Frekuensi } \\
(\%) / \\
\text { Frequency } \\
(\%)\end{array}$ \\
\hline $\begin{array}{l}\text { Kepala keluarga/ } \\
\text { Householder }\end{array}$ & 36.350 .000 & \multirow[b]{2}{*}{22.236 .763} & 93,81 & 33.881 .400 & & 74,93 \\
\hline Utama/Main & 22.850 .000 & & & 23.621 .400 & 26.421 .042 & \\
\hline Sampingan/Side & 13.500 .000 & 15.031 .966 & & 10.260 .000 & 7.334 .576 & \\
\hline $\begin{array}{l}\text { Anggota rumah tangga I } \\
\text { Household member }\end{array}$ & 2.400 .000 & & 6,19 & 11.333.333 & \multicolumn{2}{|r|}{25,07} \\
\hline - Utama/Main & 2.400 .000 & & & 11.333.333 & 10.599 .37 & \\
\hline $\begin{array}{l}\text { - Sampingan (Perikanan)/ } \\
\text { Side (Fisheries) }\end{array}$ & - & & & & & \\
\hline $\begin{array}{l}\text { - Sampingan (non - } \\
\text { Perikanan)/ }\end{array}$ & & & & & & \\
\hline Side (non Fisheries) & - & & & & & \\
\hline $\begin{array}{l}\text { Pendapatan rumah } \\
\text { tangga /Household } \\
\text { Income }\end{array}$ & 38.750 .000 & & 100 & 45.214 .733 & & 100,00 \\
\hline
\end{tabular}

Sumber: Data Primer (diolah), 2010/Source: Primary Data (Processed), 2010

segar dari hasil budidaya sendiri tetapi tidak jarang hasil pembelian. Bahan lauk lain yang juga dikonsumsi antara lain telur, tempe dan tahu. Responden jarang mengkonsumsi ikan olahan laut, ikan olahan tawar, daging sapi dan kambing. Jenis bahan lain yang juga dikonsumsi oleh responden adalah minyak goreng, gula, kopi, teh, bumbu-bumbu, makanan jadi, minuman jadi, rokok dan susu. Kebutuhan yang perlu pengeluaran misalnya rekening listrik, pendidikan, elpiji dan perlengkapan mandi/cuci dan air isi ulang. Selain konsumsi yang bersifat rutin mingguan dan bulanan juga terdapat pengeluaran yang sifatnya tahunan yaitu pendidikan anak, pajak bumi bangunan, dan sandang. Sebagian besar responden tidak mengikuti arisan, hanya beberapa responden saja yang mengikuti arisan uang dan arisan ini dijadikan sebagai tabungan. Pengeluaran untuk hajatan juga menjadi bagian kebutuhan responden meskipun biaya yang dikeluarkan tidak besar.
Data pada Tabel 7 menunjukkan bahwa pengeluaran konsumsi rumah tangga untuk skala mikro relatif lebih besar dibandingkan skala kecil. Hal ini dikarenakan beberapa hal misalnya perbedaan rata-rata jumlah anggota rumah tangga, jumlah anggota rumah tangga yang masih sekolah, preferensi konsumsi dari rumah tangga itu sendiri serta gaya hidupnya. Konsumsi pangan untuk rumah tangga dengan skala usaha mikro lebih besar dibandingkan skala kecil sedangkan untuk konsumsi non pangan rumah tangga skala usaha kecil lebih besar dibandingkan skala mikro.

Nilai konsumsi protein hewani rumah tangga perikanan berdasarkan tabulasi data hasil wawancara lebih besar konsumsi non ikannya dibandingkan protein hewani yang berasal dari ikan. Namun bila dilihat dari volumenya, konsumsi ikan jauh lebih besar lebih besar dibandingkan non ikan. Secara lengkap konsumsi protein hewani baik yang berasal dari ikan dan non ikan dapat dilihat 


\section{Tabel 7. Konsumsi Pangan dan Non Pangan Rata-rata Rumah Tangga Perikanan per Tahun di Desa Cikidang Bayabang, Cianjur, 2010}

Table 7. Average of Food and Non Food Consumption of Fish Culture Household per Year in Cikidang Bayabang, Cianjur, 2010

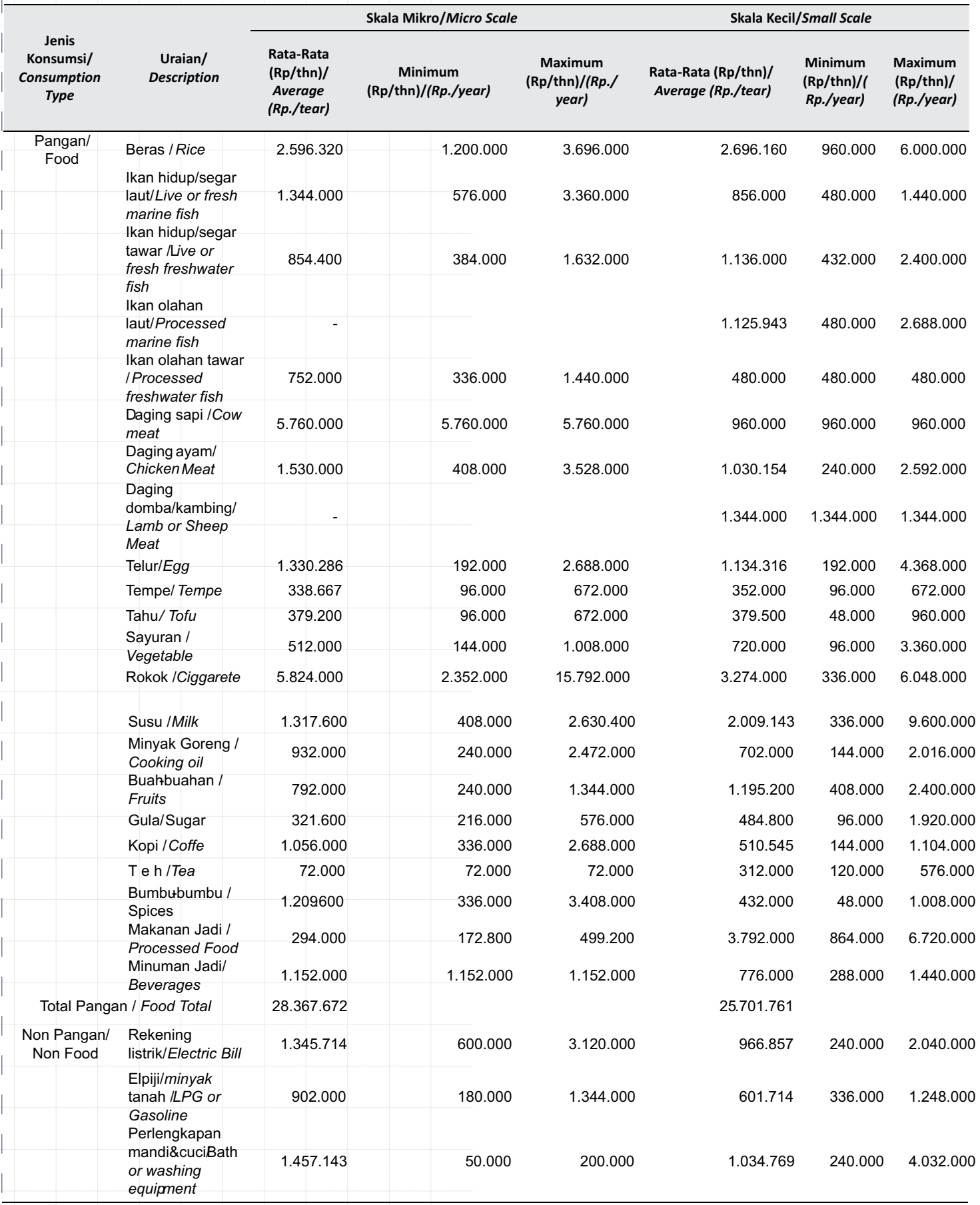


Lanjutan Tabel 7/Continue Table 7

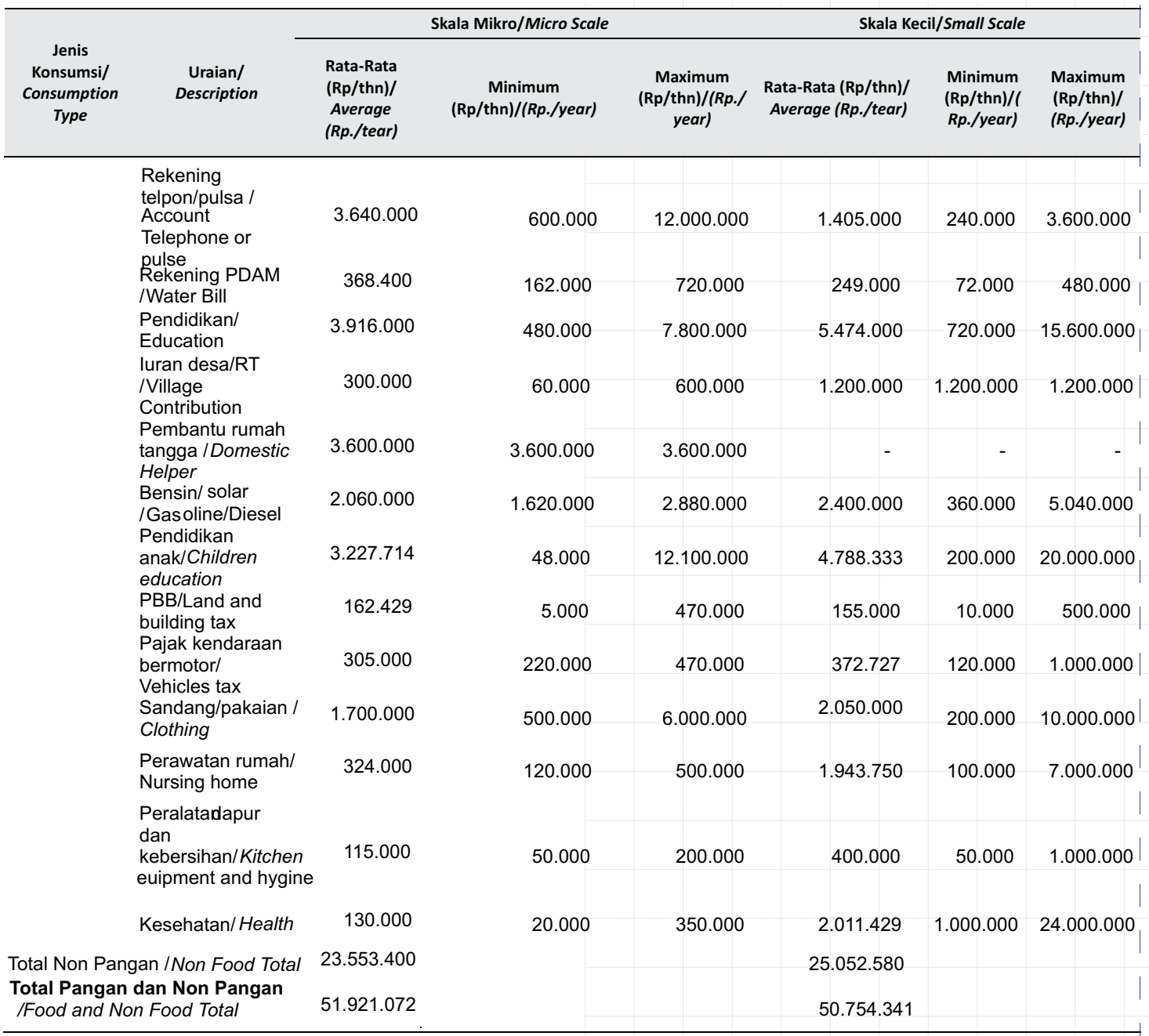

Sumber: Data Primer (diolah), 2010/Source: Primary Data (Processed), 2010

pada Tabel 8. Konsumsi ikan per kapita antara skala mikro dan kecil tidak berbeda jauh, untuk skala mikro konsumsi ikan per kapita adalah sebesar $67 \mathrm{~kg} / \mathrm{kapita} / \mathrm{tahun}$ sedangkan skala kecil adalah sebesar $65 \mathrm{~kg} / \mathrm{kapita} / \mathrm{tahun}$.

\section{Kelembagaan Usaha Tipologi Budidaya Ikan di KJA}

Sebagian besar pembudidaya ikan KJAdi Desa Cikidang Bayabang sebenarnya memiliki kelompok pembudidaya walaupun bersifat informal. Walaupun demikian keberadaan kelompok pembudidaya sampai saat ini kurang berperan optimal, bahkan beberapa pembudidaya belum merasakan manfaat keberadaan kelompok tersebut. Keberadaan kelompok seolah-olah hanya aktif ketika terdapat pemberian bantuan modal. Selain itu penyuluhan teknis terkait cara budidaya yang baik maupun informasi tentang benih unggul juga kurang dirasakan oleh sebagian besar pembudidaya. Informasi ataupun solusi pemecahan masalah terkait usaha budidaya lebih banyak diatasi sendiri dengan mengandalkan pengalaman yang dimiliki. 
Tabel 8. Konsumsi Ikan dan Non Ikan Rumah Tangga Pembudidaya per Tahun di Desa Cikidangbayabang, Cianjur, 2010

Table 8. Average of Fish and Non Fish Consumption of Fish Culture Household per Year in Cikidang Bayabang, Cianjur, 2010

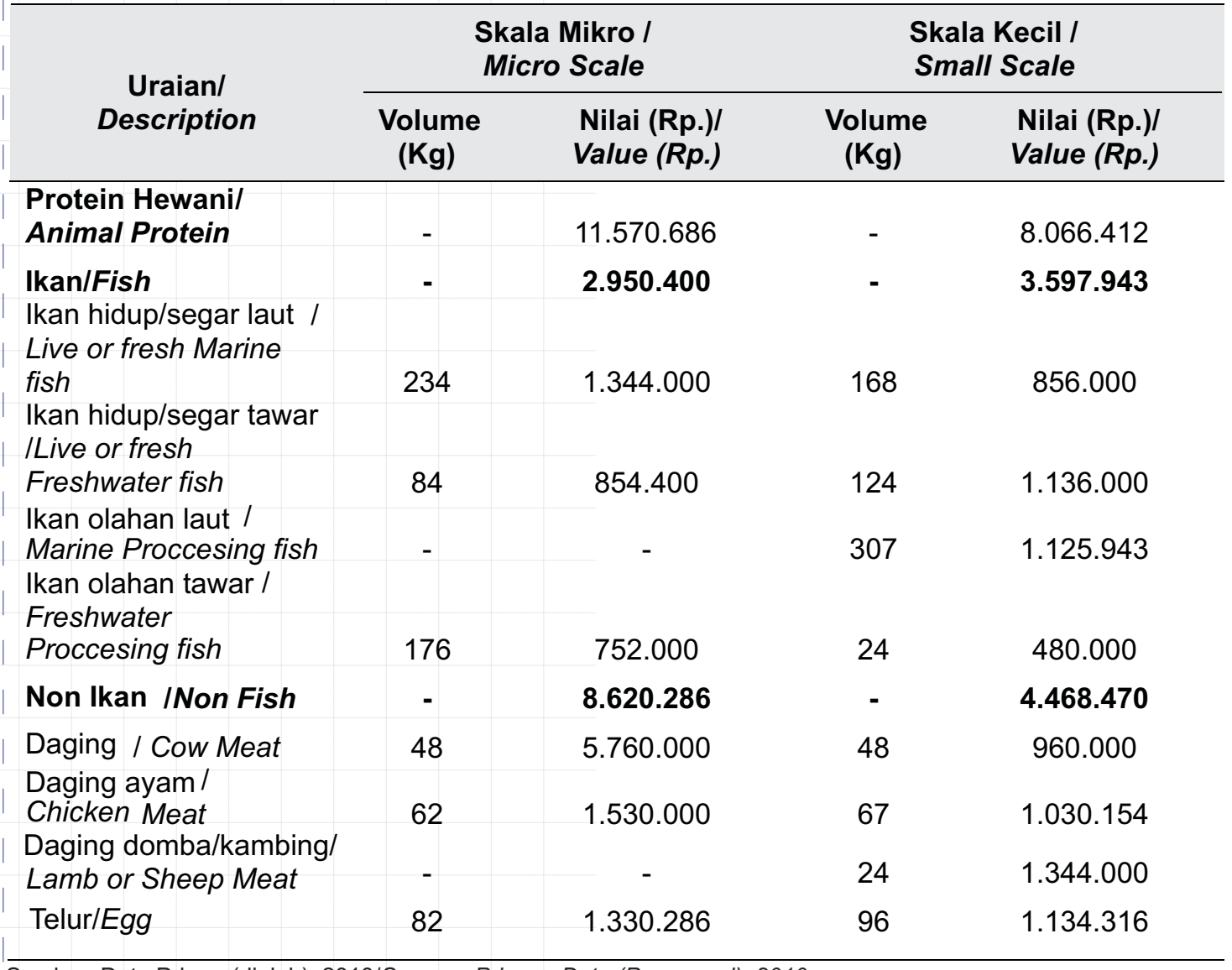

Sumber: Data Primer (diolah), 2010/Source: Primary Data (Processed), 2010

Masalah yang saat ini dirasakan oleh sebagian besar pembudidaya adalah terkait dengan penurunan kualitas sumberdaya alam yang berpengaruh terhadap penurunan produktivitas perikanan. Bimbingan teknis atau penyuluhan terkait dengan manajemen pengelolaan atau cara budidaya ikan yang baik sangat diperlukan oleh pembudidaya mengingat saat ini penyuluhan atau bimbingan teknis dari instansi terkait sangat jarang atau bahkan belum diterima oleh sebagian besar pembudidaya ikan. Selain itu adalah rendahnya harga ikan yang berpengaruh terhadap rendahnya keuntungan yang diterima pembudidaya.

Kelembagaan sarana input produksi seperti penyediaan benih, pupuk, obat-obatan sampai saat ini berjalan lancar atau kebutuhan pembudidaya dapat terpenuhi. Terkait dengan pemasaran ikan hasil produksi juga tidak terlalu sulit karena di desa tersebut banyak pedagang pengumpul yang siap menampung hasil panen pembudidaya. Salah satu model transaksi yang dilakukan dalam transaksi jual beli hasil perikanan pembudidaya adalah dengan sistem tebas yaitu pedagang 
pengumpul menawarkan nilai panen setelah mengamati kondisi kolam tanpa memanen atau ditimbang lebih dulu.

Ketersediaan dan jumlah sarana produksi pada lokasi penelitian sangat memadai dan mudah dijangkau sehingga jika responden memerlukan sarana produksi cukup tersedia. Hanya sesekali kebutuhan input (benih) harus menunggu lebih lama karena persediaan yang terbatas. Sama halnya dengan benih, ketersediaan pakan pelet juga tercukupi hanya saja pembelian secara kredit saat ini relatif susah diperoleh. Adapun jika ada kredit pakan oleh pembudidaya biasanya dilakukan menjelang ikan siap dipanen. Jumlah pedagang pakan dan benih yang sering dihubungi responden masing-masing berkisar lima (5) orang.

Kegiatan budidaya ikan pada KJA tidak memerlukan jumlah tenaga kerja yang banyak. Kegiatan usaha lebih banyak menggunakan tenaga sendiri sedangkan pemilik KJA yang menggunakan tenaga kerja sampai saat ini merasakan ketersediaan jumlah tenaga kerja masih mencukupi. Tenaga kerja yang direkrut biasanya masih ada hubungan saudara dengan pemilik KJA. Kelembagaan permodalan yang sering dihubungi oleh responden adalah kelembagaan permodalan informal seperti pedagang pengumpul. Terkait dengan masalah pinjaman, untuk keperluan usaha responden meminjam kepada pedagang pakan atau pengumpul, tetapi akhirakhir ini semakin sulit untuk dapat memperoleh pinjaman modal karena hasil panen beberapa periode terakhir kurang menggembirakan sehingga pemberi modal menjadi enggan memberikan pinjaman.

Sebagian besar pembudidaya mempunyai kebebasan untuk menjual hasil panennya kepada pedagang desa yang ada selama tidak mempunyai ikatan terhadap pedagang input atau pemberi modal. Walaupun demikian sebagian besar responden mengaku mempunyai pedagang pelanggan yang siap membeli ketika panen. Jumlah pedagang yang biasa mengambil di daerah sekitar lokasi responden berkisar
10 orang. Hasil produksi pembudidaya sebagian besar dipasarkan ke Jakarta dan Bandung.

Kelembagaan kelompok usaha tidak ditemui pada lokasi penelitian walaupun pernah ada kelompok usaha tetapi sudah lama tidak ada aktifitas organisasi lagi. Kelompok usaha yang ada saat ini tidak mengkhususkan pada bidang perikanan. Sementara untuk kegiatan penyuluhan sangat jarang diterima oleh pembudidaya. Reponden yang mengetahui informasi penyuluhan relatif rendah yaitu antara $3-13 \%$ saja. Beberapa jenis penyuluhan yang diketahui oleh responden meliputi informasi mengenai teknologi pembenihan ikan, teknologi pendederan ikan, teknologi pembesaran ikan dan teknologi pembuatan pakan. Frekuensi penyuluhan yang jarang diperburuk dengan tingkat kepedulian responden yang masih rendah untuk mengikuti penyuluhan. Sebagian besar responden ketika mendapatkan masalah mengenai usaha budiaya, hanya berusaha mencari informasi pada rekan sesama pembudidaya dan mengandalkan pengalaman usaha sendiri atau bahkan dibiarkan saja.

Kelembagaan usaha yang sudah ada jika dapat berperan optimal akan mampu mengurangi atau mengatasi masalah yang dihadapi. Keberadaan kelembagaan usaha yang optimal dapat berperan dalam membentuk kerjasama pembudidaya dalam kerjasama permodalan, sarana memperoleh informasi teknis baik yang diperoleh oleh sesama pembudidaya maupun penyuluh perikanan, dan kerjasama dalam menjaga keamanan KJA. Selama ini informasi penyuluhan oleh penyuluh perikanan belum sampai ke pembudidaya ikan KJA karena belum adanya kelembagaan usaha yang solid.

\section{Aspek Ekologi Usaha Budidaya Ikan}

Kualitas sumber daya perairan di Waduk Cirata dari tahun ke tahun terus mengalami penurunan. Beberapa hasil penelitian menyebutkan bahwa penurunan kualitas perairan dipercaya lebih banyak ditimbulkan 
oleh kegiatan perikanan itu sendiri, khususnya oleh limbah pakan. Dalam penelitian Gunawan et. al, disebutkan bahwa terjadi fenomena perilaku penurunan kualitas perairan di Waduk Cirata terutama yang mencakup meningkatnya komponen nutrien $\mathrm{C}$, menurunnya kandungan oksigen tersebut DO (Disolved Oxygen), dan meningkatnya kebutuhan oksigen biologis BOD (Biological Oxygen Demand). Dampak penurunan kualitas perairan dapat dirasakan oleh pembudidaya ikan dengan semakin rendahnya nilai konversi pakan. Rata-rata berat hasil panen ikan yang dapat diperoleh pembudidaya ikan hanya mencapai 50-60 \% dari jumlah pakan yang diberikan.

Nilai konversi pakan yang rendah menyebabkan jumlah pakan yang dikeluarkan semakin besar sehingga biaya variabel (pakan) menjadi tinggi. Kondisi tersebut menyebabkan ikan hasil panen harus bersaing dengan produk ikan yang dihasilkan daerah lain. Ikan mas Waduk Jatiluhur mempunyai nilai konversi pakan sampai $70 \%$ dari berat pakan sehingga untuk menghasilkan berat ikan yang sama hanya memerlukan biaya pakan yang lebih rendah. Tingginya nilai konversi pakan di daerah tersebut menyebabkan harga ikan lebih murah yang berimbas pada harga ikan di Waduk Cirata.

Kualitas perairan yang menurun juga berakibat pada mudahnya penyakit menyerang ikan. Beberapa masalah yang dihadapi oleh kegiatan ini diantaranya adalah seringnya terjadi "umbalan" (overturn) yang mengakibatkan kematian massal pada ikanikan dalam KJA. Kerugian ekonomi yang ditimbulkan oleh adanya peristiwa umbalan yang merupakan fenomena alamiah ini juga signifikan. Penyakit yang biasa menyerang ikan mas di KJA adalah Koi Herpes Virus (KHV). Virus ini biasa menyerang ketika suhu waduk turun sampai di bawah $25^{\circ} \mathrm{C}$ akibat hujan yang terus menerus sehingga penyakit KHV merebak dan menimbulkan kematian pada ikan Mas yang dipelihara di KJA oleh pembudidaya ikan. Antisipasi yang biasa dilakukan pembudidaya saat ini hanyalah memanen ikan lebih awal sebelum masa panen jika tanda-tanda cuaca buruk mulai tiba.

\section{KESIMPULAN DAN IMPLIKASI KEBIJAKAN}

\section{Kesimpulan}

Usaha budidaya ikan pada keramba jaring apung di Desa Cikidang Bayabang dikelompokkan ke dalam dua (2) skala usaha yaitu skala mikro dengan jumlah $\mathrm{KJA}<2$ unit dan skala kecil dengan jumlah KJA sebanyak 2-10 unit. Jenis ikan yang dibudidayakan adalah ikan nila, mas dan bawal dengan pola budidaya monokultur dan polikultur antara ikan mas dan nila. Keuntungan usaha budidaya ikan pada KJA dalam satu tahun antara skala mikro dan kecil relatif cukup signifikan yaitu sekitar Rp. 4.995.188 untuk skala mikro dan Rp. 57.343.060 untuk skala kecil. Kondisi ini dapat terjadi karena adanya usaha dari pembudidaya ikan skala kecil untuk menurunkan intensitas produksinya dengan cara membiarkan beberapa KJA dalam keadaan kosong atau mengurangi jumlah pakan yang diberikan. Nilai $\mathrm{R} / \mathrm{C}$ rasio pada skala usaha mikro dan kecil yang berkisar antara 1,06 dan 1,31 menunjukkan usaha tersebut hanya memberikan keuntungan yang rendah.

Perbedaan rata-rata pendapatan utama rumah tangga responden antara skala mikro dan kecil cukup signifikan, dengan selisih sekitar Rp. 6.000.000,-. Pendapatan kepala keluarga yang berasal dari sampingan sekitar $50 \%$ dari pendapatan dari usaha utamanya. Konsumsi rumah tangga, bahan pokok yang dikonsumsi adalah nasi dan bahan lauk protein yang sering dikonsumsi adalah ikan segar dari hasil budidaya sendiri tetapi tidak jarang hasil pembelian. Bahan lauk lain yang juga dikonsumsi antara lain telur, tempe dan tahu. Responden jarang mengkonsumsi ikan olahan laut, ikan olahan tawar, daging sapi dan kambing. Konsumsi ikan per kapita antara skala mikro dan kecil tidak berbeda jauh, untuk 
skala mikro konsumsi ikan per kapita adalah sebesar $67 \mathrm{~kg} / \mathrm{kap}$ ita/tahun sedangkan skala kecil adalah sebesar $65 \mathrm{~kg} / \mathrm{kapita} / \mathrm{tahun}$. Kelembagaan usaha yang ada belum berjalan optimal dan sebagian besar pembudidaya belum menjadi anggota dalam kelembagaan usaha. Kenaikan harga input dan tidak stabilnya harga output (ikan) memperburuk rendahnya keuntungan yang dapat diperoleh pembudidaya ikan pada KJA.

\section{Implikasi Kebijakan}

Produktivitas dan keuntungan usaha pembudidaya ikan pada KJA yang rendah memerlukan upaya mendesak yang mengarah pada perbaikan kualitas sumber daya perairan sehingga mampu meningkatkan produktivitas ikan yang secara linier akan meningkatkan keuntungan usaha. Untuk itu perlu dilakukan kegiatan penelitian lanjutan terkait kualitas sumber daya perairan yang diharapkan mampu memberikan langkah-langkah perbaikan kualitas perairan.

Pembentukan dan pendampingan kelembagaan usaha juga merupakan hal yang mendesak untuk dilakukan sehingga manajemen usaha pembudidaya ikan semakin baik dan mengacu pada cara budidaya ikan yang baik dan benar sesuai dengan standar nasional maupun internasional. Pemerintah perlu memfasilitasi rantai pemasaran ikan, serta menjaga stabilitas harga ikan. Selain itu, usaha paska produksi yang mampu mengolah ikan hasil produksi sehingga mempunyai nilai tambah perlu dikembangkan.

\section{DAFTAR PUSTAKA}

Annonimous. 2010. Laporan Kegiatan Tahun 2009 Koordinator Petugas Perikanan Waduk Cirata Wilayah Kabupaten Cianjur. Dinas Peternakan Perikanan dan Kelautan Kabupaten Cianjur, Cianjur. 56 hal.
2008. Data Potensi, Produksi dan Ekspor/Impor Kelautan dan Perikanan 2007. Departemen Kelautan dan Perikanan. Jakarta.197 hal.

Gunawan, Wawan, Zahidah dan D. Mulyanti. 2007. Model Eutrofikasi untuk Merancang Kebijakan Pengelolaan Waduk yang Berkelanjutan melalui Pendekatan System Dynamics (The System Dynamics Approach of Eutrofication Model of the policy design on Reservoir Sustainability Management). www.pustaka.unpad.ac.id/model eutrofikasi untuk merancang kebijakan pengelolaan waduk. Diakses pada tanggal 16 Mei 2010.

Handayani, R. 2007. Optimalisasi Distribusi Pemasaran Ikan Mas Hidup dari Waduk Cirata, Propinsi Jawa Barat. Skripsi. Fakultas Perikanan dan IImu Kelautan Institut Pertanian Bogor, Bogor. 158 hal.

Hardjamulia, A.N. Suhenda dan Krismono. 1991. Budidaya Ikan Air Tawar dalam Keramba Jaring Apung Mini. Pusat Penelitian dan Pengembangan Perikanan. Jakarta. 55 hal.

Kamaluddin, L.M., 1994. Strategi Penyiapan dan Kualitas SDM Pada Pembangunan Agribisnis Perikanan Indonesia. Makalah Seminar Sehari Himpunan Sosial Ekonomi Perikanan. IPB. Bogor. 20 hal.

Kartamihardja, E., 1988. Analisis "cohort" dan Pengelola Stok Ikan Tawes, (Puntius goneonotus) di Waduk Juanda, Jawa Barat. Bull. Pen. Perik. Darat 7(1): 14-21

Prihadi, T.H. 2005. Pengelolaan Budidaya Ikan Secara Lestari di Waduk (Studi Kasus di Perairan Waduk Cirata Jawa Barat). Disertasi Pasca Sarjana IPB, Bogor. 257 hal.

Ryding, S.O. dan W. Rast. 1989. The Control of Eutrophication of Lakes and Reservoirs. The Parthenon Publishing Group. Paris. $235 p$. 